\title{
POWER UNITS AND POWER SUPPLY SYSTEMS IN UAV
}

\author{
Leszek Cwojdziński ${ }^{1}$, Mirosław Adamski ${ }^{2}$ \\ ${ }^{1}$ Inspectorate for Implementation of Innovative Defense Technologies, \\ Nowogrodzka Street, 47a, 00-695 Warsaw, Poland \\ ${ }^{2}$ Faculty of Aviation and Aeronautics, Polish Air Force Academy, \\ Dywizjonu 303, 35, 08-521 Dęblin, Poland \\ E-mail: tetrazen@wp.pl (corresponding author)
}

Received 11 November 2013; accepted 28 February 2014

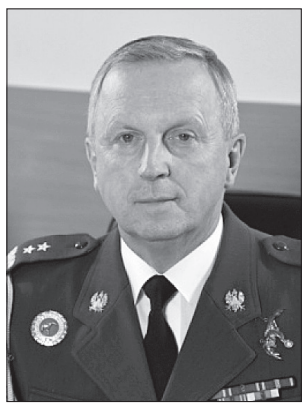

Leszek CWOJDZIŃSKI, PhD, PAF Maj. Gen. pil.

Education: Polish Air Forces Academy in Dęblin; Master's degree in Aviation Psychology in MCS University, Lublin; military studies in memorial Jurij Gagarin Air Force Academy, Russia. In 2003 - PhD degree in Military University of Technology, Warsaw, specialization Teledetection.

Affiliations and functions: an experienced commanding officer and instructor-pilotteacher of many Polish military pilot generations. Inspecting Professor and guest speaker in the National Defense University of Warsaw. Participant of many national and international scientific symposiums and conferences. Organizer of conferences dedicated for innovative technologies in safety and security environment.

Research interests: optimization of exploitation and military utilization of autonomous unmanned platforms.

Publications: author of numerous publications in the fields of flight safety issues, technical support of air missions, aerial navigation and aircraft exploitation.

Present position: acting chief of the Inspectorate for Implementation of Innovative Defense Technologies.

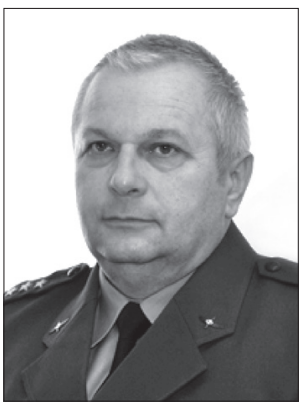

Mirosław ADAMSKI, PhD, Eng. Col.

Education: MSc (Eng) degree in Electro Mechanics, the Military University of Technology, Warsaw, the Faculty of Mechatronics and Aviation; PhD at the National Defense University of Warsaw, the Faculty of Aviation and Air Defense, specialization: use of weapon and military equipment.

Affiliations and functions: 1994 to 2002 - Assistant Professor; 2002 to 2012 - the Head of the Armament Department; 2012 to present - the Vice Dean of the Aviation Faculty, Polish Air Force Academy in Dęblin, Aviation Faculty.

Research interests: aircraft weapon systems, UAV, NCW.

Publications: author and co-author of 9 student text books, 42 research papers, 25 scientific articles and author/co-author of 53 conference papers.

\begin{abstract}
One of the major tasks in the process of designing future unmanned aerial vehicles is the appropriate choice of a propulsion system and a power source. Depending on the role and size of a given UAV, the following engines are used: electric, jet, turbine and piston (combustion). The following paper also analyses the faultiness of UAVs. Moreover, the most appropriate propulsion systems and power sources depending on the type and description of the mission performed by a UAV are recommended.
\end{abstract}

Keywords: unmanned air vehicles, designing, propulsion system, power source, hybrid, solar cells 


\section{Introduction}

One of the most important tasks in the development phase of a UAV is the proper selection of the drive unit. It involves the selection of such a system which enables the best use of the characteristics of the airframe and produces appropriate thrust to meet all the tactical requirements for an unmanned aerial vehicle. It is also significant that a UAV should poses an appropriate lifting capacity required for carrying combat agents as well as for the completion of a task (Earth ... 2006).

\section{Presentation of power units used in UAVs}

1. Engines powered by chemical or nuclear energy:

1.1. Thermal engine.

1.2. External combustion engine.

1.3. Internal combustion engine.

1.3.1. Nano engine.

1.3.2. Multi-fuelled engine.

1.3.3. Ion engine.

1.3.4. Piston engine:

- spark-ignited;

- self-ignited or:

- with a reciprocating piston (including a rotary piston);

- with a rotary piston;

- inline;

- opposed;

- multi-row;

- radial or:

- two-stroke;

- four-stroke.

1.3.5. Jet engines:

- rocket;

- straight:

- without a compressor:

- ramjet;

- pulse jet;

- with a compressor:

- motor jet;

- turboprop;

- turbojet:

- with an axial compressor;

- turbofan turbojet;

- turbofan.

2. Electric engine.

\section{Piston engine}

Pistons moving in the cylinders are responsible for generating power. The pistons are connected with the crankshaft which produces torque. The most common piston engine is an internal combustion piston engine.

\subsection{Two-stroke engine}

A two-stroke engine is a kind of an internal combustion engine which performs two cycles in one shaft revolu- tion (Fig. 1). The high power achieved in this way is an asset in comparison with other engines. Such a design makes the engines relatively lightweight, also they have high power to weight ratio and are, therefore, attractive for the use in UAVs weighting up to $50 \mathrm{~kg}$.

One of their shortcomings is the fact that these engines operate at high temperature, which shortens their longevity, and oil is also burned during the work process. Therefore, two-stroke engines exhaust more fumes compared with other internal combustion engines. Moreover, the composition of the air-fuel mixture in carburetor internal combustion engines is dependent on the altitude. The higher the altitude, the less oxygen is available, which causes incomplete combustion and, consequently, loss of power. The solution to this problem is the use of fuel injection as the amount of oxygen in the intake system is measured and an appropriate quantity of fuel is adjusted (Unmanned ... 2009).
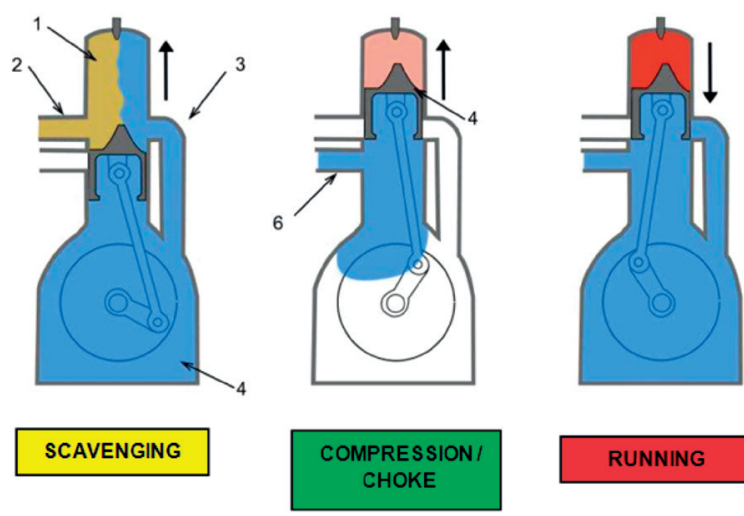

Fig. 1. Two-stroke engine work cycle

\subsection{Four-stroke engine}

Propeller drive units with four-stroke piston engines are mainly used for the propulsion of UAVs weighting more than $50 \mathrm{~kg}$. Four-stroke engines are characterized by a greater efficiency and longevity due to an efficient cooling system (Fig. 2). They have a separate lubrication system which allows abandoning the fuel-oil mixture application and results in lower exhaust emissions. Unfortunately, this type of engine, compared with a two-stroke

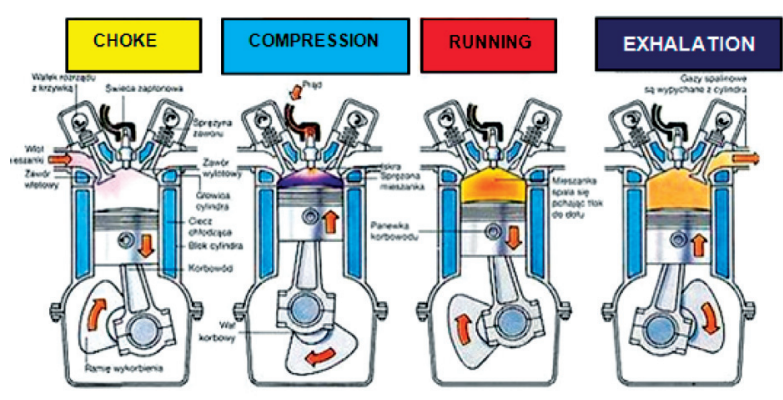

Fig. 2. Four-stroke engine work cycle 
one, contains more moving parts and, consequently, has a greater mass. Furthermore, four-stroke engines are louder and less powerful. These engines can be found in line, boxer or rotary arrangements (Valavanis 2008).

\subsubsection{Rotary engine}

In this type of engine the crankshaft (the part of the engine mounted to the construction) is stationary while the engine housing (connected to the propeller) together with the cylinders are movable.

Engine cylinders are constructed in a radial configuration (less commonly in a double radial one or opposite to each other) (Fig. 3). The air-fuel mixture is supplied by a crankshaft, with the intake through the cylinder slots (two-stroke) or valves in the cylinder heads (four-stroke). The outlet is in the head (the valve is opened by a follower).

Due to good cooling, it is possible to apply a high level of compression. This type of engine is characterized by a lightweight design and good balance. However, the oil and fuel consumption is high; it has limited rotation speed and a tendency to overheat.

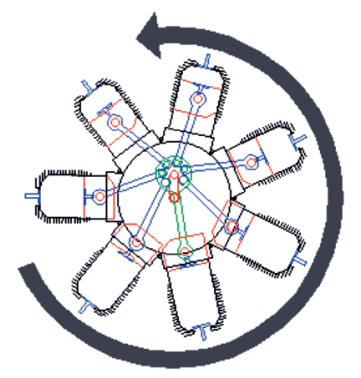

Fig. 3. Radial-type engine

\subsubsection{Wankel engine}

A Wankel engine is a type of internal combustion engine which works using the piston rotary movement (Fig. 4). The lubrication is analogous to that of a two-stroke engine, which eliminates the need to develop a separate lubrication system.

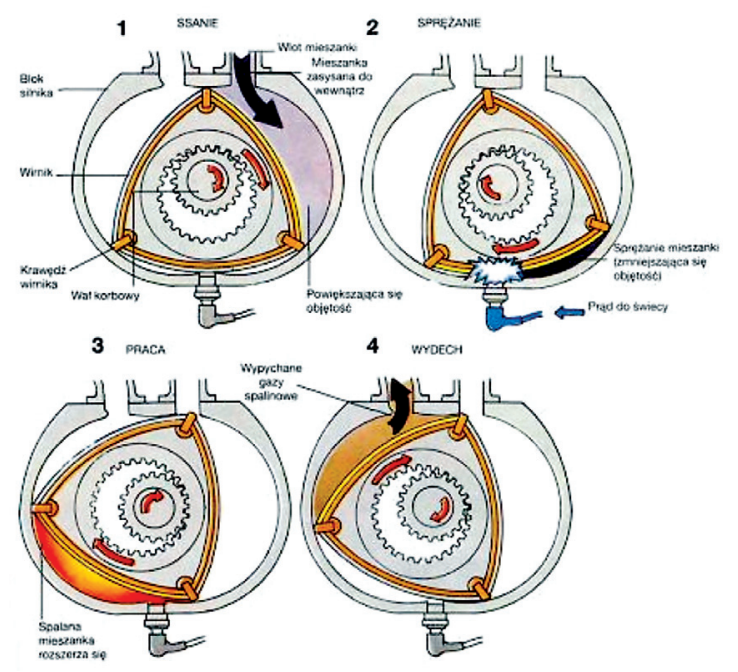

Fig. 4. Wankel engine work cycle
A big advantage of using Wankel engines in aviation is their small size in comparison with piston engines with similar power, also their quick response to throttle movements. Their application in UAV shows an upward trend.

\subsubsection{Electric-diesel hybrid}

A hybrid consists of two engines - a small diesel or petrol engine, working on permanent RPM assuring the best efficiency, and an electric one, providing additional power when needed, for instance, when an aircraft takes off or a vehicle with wheels goes uphill. There are two possibilities of their mutual arrangement - in parallel or series. In the parallel one, both the electric and the internal combustion engines move the gear at the same time. Both engines are independently coupled to a gear to ensure drive. In a series arrangement, the internal combustion engine never drives the gear directly. It drives a generator which can supply power to the electric engine and also charge the batteries. The electric engine only drives the gear. Hybrids can reduce fuel consumption by $20 \%$.

\subsubsection{Six-stroke engine}

The class of six-stroke engines offers several solutions. The most promising one is based on the design combining a four-stroke engine with a kind of a steam engine. The above-mentioned engine is characterized by high thermal efficiency and reduced weight since it does not require a cooling system; however, this advantage is abrogated by the additional weight of the pressurized cylinder. At present, the major potential of six-stroke engines is expected to be realised in some branches of the engineering industry; however, when it comes to the UAV propulsion, these are only theoretical deliberations, and the engine itself requires appropriate modifications to enable utilization in the air.

\subsubsection{Disk engine}

This is an example of internal combustion engine employing two discs. One disc is used for the mixture suction and compression and the other one for the expansion and exhaust removal. The torque is transmitted by the shaft. The disc is connected with the drive shaft in the shape of the letter ' $z$ '. This connection causes shaft fluctuations similar to gyro fluctuations with a falling number of revolutions.

The advantage of this solution is the lack of the contact of the upper part of the disc with the combustion chamber interior, which makes the application of lighter and cheaper materials at some phase of the construction possible. Working strokes are performed by the steady fluctuation of the cyclic disc, which results in less vibration compared with traditional internal combustion engines. In small disc engines the output 
torque is directly transmitted to the propeller drive shaft, so there is no power loss in the gear. This enables the engine to achieve four times more power compared with traditional solutions.

Currently, a disc engine is a theoretical consideration due to the unsolved problems related to stroke coordination, fuel injection and spark plug operation.

\section{Jet engine}

The jet propulsion is created by discarding combustion products (gases) with great rapidity. This induces thrust which acts in the opposite direction.

\subsection{Rocket engine}

There are two types of rocket engines, such as operating on liquid fuels or solid fuels.

The engines using liquid fuel carry an oxidizer and a liquid reducer (for instance: liquid oxygen and hydrogen). Due to appropriate fuel injection to the combustion chamber, it is possible to control the engine's thrust.

In the engines using solid fuel, the combustion chamber is also a fuel cell (Figs 5-6). The fuel can be combusted frontally or in channels. The drawback of this type of engine is the lack of the possibility of thrust control as well as engine shut down before the whole amount of fuel has been burned (Valavanis 2008).

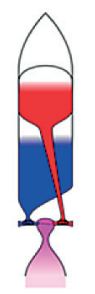

Fig. 5. Rocket engine using liquid fuel (blue indicates fuel, red - oxidizer, pink - combustion)

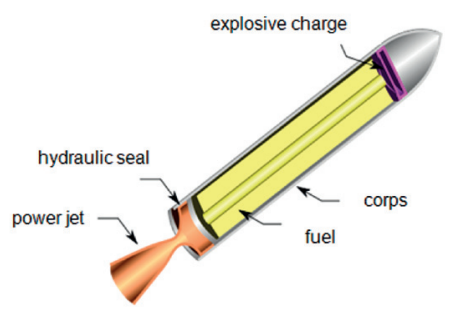

Fig. 6. Rocket engine using solid fuel

\subsection{Jet engine with a compressor}

The air is sucked by the compressor, it mixes with the fuel in the combustion chamber and is burned there (the ignition is due to hot exhaust gases) (Fig. 7). Hot exhaust gases drive the turbine, which is coupled with the compressor by the shaft (the turbine drives the compressor). The produced thrust is the momentum difference of inlet and outlet gases (Valavanis 2007).

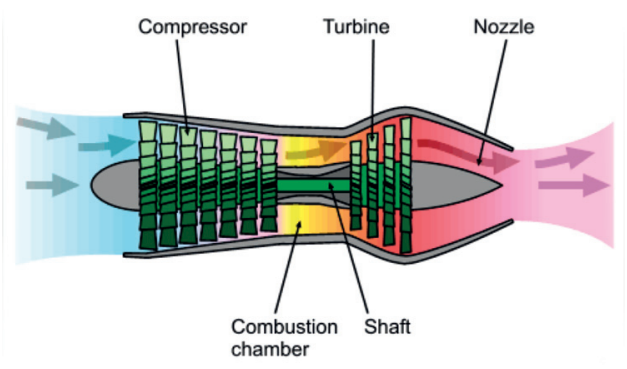

Fig. 7. Axial-flow compressor engine

At subsonic speed this engine is less efficient and fuel consumption is higher. At high supersonic speed it can overheat (high pressure and temperature), and both the compressor and turbine may be damaged. For the propulsion of small unmanned aerial vehicles, jet engines producing a thrust of 15-30 daN and weighing about $2 \mathrm{~kg}$ are used. Due to high rotational speed, the method of lubrication and the temperature of exhaust gases, the working time of such an engine is limited to about 25-30 hours. During operation, such an engine constantly needs an external source of power supply in order to control the operational parameters and to drive the fuel pump.

For this reason, not only the size of the fuel tank but also onboard battery capacity that is used to supply power to other airframe parts: steering, monitoring and communications, is limited in small UAVs (Valavanis 2007).

\subsection{Turboprop engine}

The propulsion method for this engine type is a gas turbine used for moving the external drive propeller (Fig. 8). The propeller is coupled with the turbine by a gear (reduction gear), which transfers the input low torque at high RPM into the output high torque at low RPM. The propeller is usually self-revolving (Hołdanowicz et al. 2000).

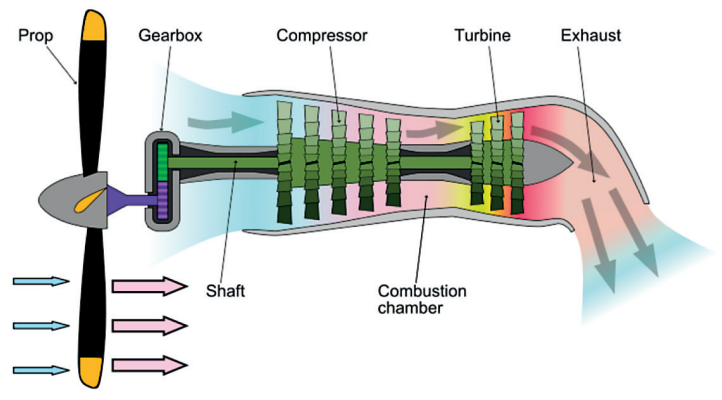

Fig. 8. Turboprop engine

This engine is efficient at low cruising speed, has a small mass, and its maintenance is less complicated when compared with other engine types.

\section{Power units in UAVs weighting more than $50 \mathrm{~kg}$}

In UAVs weighting more than $50 \mathrm{~kg}$, propeller drive units with two-stroke or four-stroke piston engines are usually used for the propulsion. It is characteristic 
that in UAVs weighting between $50 \mathrm{~kg}$ and $100 \mathrm{~kg}$ the engines of different producers are used, whereas most UAVs with the mass of 100-500 kg are equipped with a rotary piston engine produced by a British company, UAV Engines Ltd. However, UAVs weighting more than $500 \mathrm{~kg}$ often use engines produced by Rotax (Valavanis 2007). Their utilisation is conditioned by their high reliability, relatively long periods between overhauls (several hundred hours), availability of spare parts and relatively low prices, which are several times lower than the prices of the engines produced solely for UAVs.

These engines (Tab.) mainly use a carburetor power supply, but power systems with low-pressure injection are becoming more and more popular. The engines with the power injection provide a better adjustment of the quality and composition of the mixture to the changeable flight conditions and allow lower fuel consumption. Moreover, it should be taken into account that the piston engines with a carburetor power supply are susceptible to intake system icing at the ambient temperature which is higher than $+20^{\circ} \mathrm{C}$ (even up to $38^{\circ} \mathrm{C}$ ) at a relative humidity, even lower than $30 \%$, whereas in the piston engines with power injection this danger rarely occurs at a temperature higher than $5{ }^{\circ} \mathrm{C}$. Many companies are also working on aviation Diesel engines with low power. The power units in unmanned aerial vehicles are mainly equipped with fixed pitch propellers. Only strategic UAVs flying at high altitude have variable pitch propellers. Although a variable pitch propeller ensures better utilization of the engine in changeable flight conditions, it complicates the construction of the drive unit and increases its mass. Propellers are usually driven directly by the engine crankshaft, but in some cases, especially in big UAVs, there is a need for a reduction gear (Valavanis 2008).

Table. UAVs specification

\begin{tabular}{|c|c|c|}
\hline \multicolumn{3}{|c|}{ RQ-2 Pioneer (Valavanis 2007) } \\
\hline Engine & $\begin{array}{l}\text { two-stroke, two-cylinder } \\
\text { Sachs engine in boxer } \\
\text { arrangement with } 26 \\
\text { HP }(19 \mathrm{~kW}) \text { power or, } \\
\text { alternatively, RQ- } 2 \text { c: UEL } \\
\text { AR-741 rotary engine with } \\
38 \mathrm{HP}(28.3 \mathrm{~kW}) \text { power }\end{array}$ & \\
\hline Max. speed & $200 \mathrm{~km} / \mathrm{h}$ (110 kts) & \\
\hline Range & 5 hours of flight $(185 \mathrm{~km})$ & \\
\hline Max. ceiling & $4.600 \mathrm{~m}(15.000 \mathrm{ft})$ & \\
\hline \multicolumn{3}{|c|}{ RQ-5 Hunter (Valavanis 2007) } \\
\hline \multirow{2}{*}{$\begin{array}{l}\text { Engine } \\
\text { Max. speed }\end{array}$} & $\begin{array}{l}2 \times \text { two-cylinder, four- } \\
\text { stroke Moto Guzzi with } \\
136 \mathrm{HP}(100 \mathrm{~kW}) \text { power }\end{array}$ & \multirow{4}{*}{$x^{2}+5 x$} \\
\hline & $204 \mathrm{~km} / \mathrm{h}$ & \\
\hline Range & $1.800-2.000 \mathrm{~km}$ & \\
\hline Max. ceiling & $4.600 \mathrm{~m}(15.000 \mathrm{ft})$ & \\
\hline
\end{tabular}

MQ-1 Predator (Aircraft ... 2013)

\begin{tabular}{|l|l|l|}
\hline Engine & $\begin{array}{l}\text { four-cylinder Rotax 914F } \\
\text { with 115 HP power }\end{array}$ & \\
\hline Max. speed & $217 \mathrm{~km} / \mathrm{h}$ & \\
\hline Range & $726 \mathrm{~km}$ & \\
\hline Max. ceiling & $4.600 \mathrm{~m}(15,000 \mathrm{ft})$ & \\
\hline
\end{tabular}

\begin{tabular}{|c|c|c|}
\hline \multicolumn{3}{|c|}{ MQ-9 Reaper (Aircraft ... 2012) } \\
\hline Engine & $\begin{array}{l}\text { turboprop Honeywell } \\
\text { TPE331-10GD with } 900 \\
\text { HP power }\end{array}$ & \\
\hline Max. speed & $483 \mathrm{~km} / \mathrm{h}$ & \\
\hline Range & $5.925 \mathrm{~km}$ & \\
\hline Max. ceiling & $15.240 \mathrm{~m}(50.000 \mathrm{ft})$ & \\
\hline \multicolumn{3}{|c|}{ Tu-141 (Virtual ... 2013) } \\
\hline Engine & $\begin{array}{l}\text { turbojet Tumanski KR-17A } \\
\text { with } 19.6 \mathrm{kN} \text { thrust }\end{array}$ & \\
\hline Max. speed & $1.100 \mathrm{~km} / \mathrm{h}$ & \\
\hline Range & $1.000 \mathrm{~km}$ & \\
\hline Max. ceiling & $6.000 \mathrm{~m}$ & \\
\hline
\end{tabular}

RQ-4 Global Hawk (Unmanned ... 2009)

\begin{tabular}{|l|l|l|}
\hline Engine & $\begin{array}{l}\text { turbofan Rolls-Royce F137- } \\
\text { RR-100 with 34 kN thrust }\end{array}$ & \\
\hline Max. speed & $840 \mathrm{~km} / \mathrm{h}$ & \\
\hline Range & $14.000 \mathrm{~km}$ & \\
\hline Max. ceiling & $18.288 \mathrm{~m}(60.000 \mathrm{ft})$ & \\
\hline
\end{tabular}

Modern drones used by the USA and Israel such as RQ-3 or RQ-4 have jet engines which provide higher speed and endurance, unfortunately, only rich countries can afford using them due to high operating costs. The most rarely applied power unit is the turboprop engine.

\section{Electric engine}

Light electric engines (Fig. 9) can generate torque proportional to the supplied voltage. Their design is free from moving parts, which increases their work tolerance at higher RPM. This makes electric engines more efficient than their traditional competitors. Another advantage is the fact that they produce much less pollution than the average internal combustion engine.

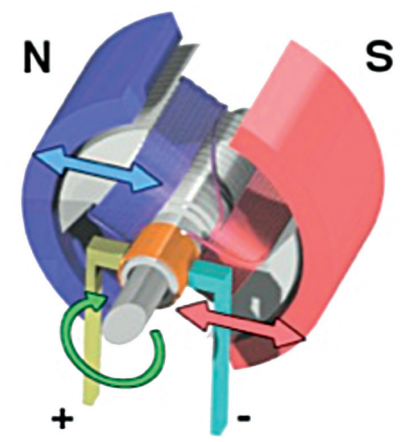

Fig. 9. Schematic representation of an electric engine 
The stable operation of an electric engine requires, unfortunately, a constant energy supply which cannot always be guaranteed due to the possible interference in the current flow. This in turn affects its reliability and, potentially, makes its stability dependent on the size of the supplied voltage. Electric engines are used in unmanned aerial vehicles weighting up to $6 \mathrm{~kg}$ (currently they are being tested for larger vehicles) (Jurecka, Bencalik 2012), for example (Fig. 10):

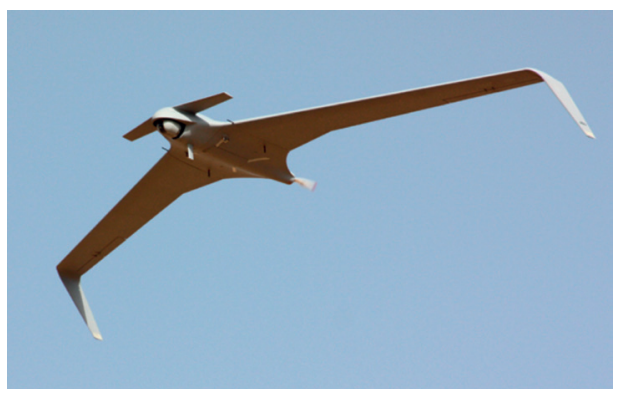

Fig. 10. Aeronautics Orbiter

\subsection{Solar power}

The first solar aircraft flew into the air in the 90s due to NASA efforts. The agency was looking for a platform to monitor the ozone hole over the Antarctica. The final result of the program was the aircraft Helios with a span of 75 meters, which was first airborne in September 1999 and two years later broke the record for level flight by remaining airborne for 40 minutes and reaching the ceiling of 29,260 meters (Fig. 11) (Jurecka, Bencalik 2012).

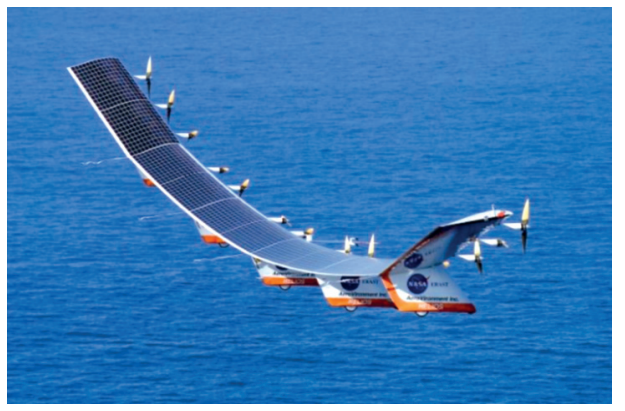

Fig. 11. UAV Helios

Solar powered aircraft do not have to land. During daylight the sun not only supplies the engines with energy but also charges capacious and lightweight batteries which are installed onboard. Hence, the aircraft gathers the 'fuel' supply required for a night flight (Military ... 2012). Therefore, its operating time can be calculated even in months. There are no thunderstorms or violent winds in the thin air, which provides a better environment for the delicate structure than the troposphere. However, the aircraft has to function properly in temperatures reaching $-70^{\circ} \mathrm{C}$. This is a serious challenge for the aircraft's structure and the batteries, whose capacity decreases as temperature drops.

\subsubsection{Elements of photo-galvanic systems}

Solar batteries, solar panels and photovoltaic modules are the devices constructed of adequately connected photovoltaic cells which use the photoelectric effect for the production of electric energy. The basic material used for the production of solar cells is silicon (Jurecka, Bencalik 2012).

Types of silicon used in solar batteries:

- monocrystalline - highest efficiency: 12-17\%, especially on a sunny day, highest durability, highest price,

- polycrystalline - high conversion efficiency: 10$15 \%$, on a cloudy day even higher than that of monocrystalline modules, durability comparable with monocrystalline silicon, price slightly lower than that of monocrystalline silicon modules,

- amorphous - slightly lower efficiency than that of monocrystalline modules. It is becoming increasingly common due to low price. It is also used in elastic solar panels in the tourism industry.

Charge controller - a device used between a solar battery and a battery. The controllers are used to keep the battery fully charged and to protect it from recharging, as well as its excessive discharging by the receivers. They also protect against the so-called "dark" current which is collected by a solar panel when there is no lighting if the panel has not been equipped with a blocking diode (Jurecka, Bencalik 2012).

Types of controllers:

- simple 1-2 stage controller which operates by pumping energy into the battery. When the required voltage is achieved, the panel is disconnected;

- 3 stage PWM;

- MPPT (Maximum Power Point Tracking) are controllers tracking maximum voltage. Controllers of this type operate in the PWM mode too. MPPT type controllers allow supplying 10-30\% more energy to the battery. They are usually more expensive than standard PWM controllers.

Types of batteries:

- Lithium-sulfur battery (Li-S) - chargeable galvanic cell. It is characterized by very high capacity. Due to low lithium density and moderate sulfur density, the Li-S batteries are relatively lightweight. The Li-S batteries have much higher capacity than the Li-ion ones. Their disadvantage is the rapidly decreasing capacity during following charging and discharging cycles (Jurecka, Bencalik 2012).

- Lithium-ion battery (LiPo or Li-ion). They have very high charging efficiency, do not need a metal housing, which reduces battery weight and facilitates the battery shaping in the device. The pos- 
sibility for denser packing and the elimination of the metal housing increases the energy density by $20 \%$ in comparison with the Li-ion batteries.

- Nickel metal hydride battery (NiMH). This type of battery does not contain toxic cadmium compounds like a NiCd battery. It has one of the highest energy densities $(360 \mathrm{MJ} / \mathrm{m} 3)$. NiMH batteries have from two to three times higher capacity than the corresponding $\mathrm{NiCd}$ ones. The NiMH technology has high energy density and uses environmentally-friendly materials. A NiMH battery offers up to $40 \%$ more energy density than a NiCd one. The NiMH batteries are more expensive than the NiCd batteries. They self-discharge faster and have a shorter longevity; however, they achieve about $30 \%$ more capacity.

\subsubsection{Hydrogen fuel cell}

A hydrogen fuel cell is a cell generating electrical energy from the oxidation reaction of the fuel which is constantly supplied from the outside. To produce electrical energy, most of the fuel cells use hydrogen at the anode and oxygen at the cathode. The process of producing energy does not change the electrode chemical nature and the electrolytes used. The huge advantage of hydrogen cells is rather small air pollution. The exhaust gases consist solely of steam neutral for the environment.

\section{Analysis of engine operating properties}

Two-stroke:

Advantages:

- two-stroke engines are widely used in unmanned aerial vehicles due to smaller weight;

- have higher $\mathrm{P} / \mathrm{W}$ ratio;

- better SPED (propulsion energy density) values.

Disadvantages:

- high noise level compared with four-stroke and Wankel engines.

Four-stroke:

Advantages:

- higher fuel economy than in turbine and Wankel engines.

Disadvantages:

- not widely used due to large weight;

- very low P / W ratio when compared with twostroke engines;

- produce a considerable amount of noise.

Wankel:

\section{Advantages:}

- lighter compared with two-stroke and four-stroke engines;

- easy start-up at low temperatures;

- middle of piston mass coincides with circular cam axis which provides full dynamic balance;
- durability and reliability which is related to work at high RPM;

- high P / W ratio.

Disadvantages:

- lower amount of generated energy, therefore, not widely used;

- low fuel economy;

- high carbon dioxide emissions;

- high fuel consumption;

- higher production costs compared with piston engines.

Turbine:

Advantages:

- higher P / W ratio than that of other types;

- very low weight compared to other engines.

Disadvantages:

- very high fuel consumption;

- have not yet been used in small unmanned aircraft due to poor fuel economy at lower scales.

Electric:

Advantages:

- more efficient than other types;

- lower weight;

- better P / W ratio.

Disadvantages:

- lower SPED (propulsion energy density) values;

- not suitable for long range missions due to low values of energy density in batteries.

\section{Nuclear-powered unmanned aircraft}

American scientists have outlined the plans for a new generation of nuclear-powered unmanned aircraft. This technology, however, has been deemed extremely dangerous and the projects have officially been made secret due to "national safety". The projects of new drones (Fig. 12) were already developed in the Fderal Research Iinstitute Sandia National Laboratories in cooperation with Northrop Grumman in 1986 (Appendix ... 2006).

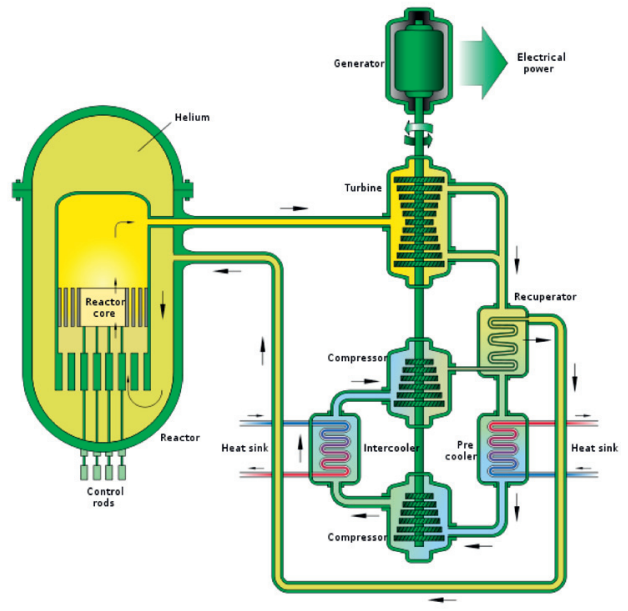

Fig. 12. $4^{\text {th }}$ generation reactor for UAV 


\section{Conclusions}

The selection of power units for unmanned aerial vehicles is a rather complicated process. Many factors should be considered during the UAV design phase. Selection is primarily based on the application of a given UAV and its operating conditions. Nowadays, the tasks which UAVs have to perform make it necessary to introduce some flexibility in the power unit selection process, as well as to consider the purchase costs of the whole aircraft since many of the feasible missions end with a partial or total destruction of the unmanned aerial vehicle (Unmanned ... 2009). The performed analysis suggests that a perspective UAV power unit should be based on an internal combustion engine with a rotating piston or one in a flat-line arrangement (boxer). It should be controlled by a digital system which allows the transmission of data of its operating parameters to a ground operator in real time. The engine should have a heavy fuel supply. The engine intake system should preferably be equipped with a dust extraction unit. Moreover, the engine should possibly have low levels of infrared radiation and noise emission. In the near future, unmanned aerial vehicles weighting more than $50 \mathrm{~kg}$ powered by electric engines fed by fuel cells are likely to appear. However, it should be remembered that the ability to achieve appropriate UAV power unit parameters is related to high costs (Kulyk et al. 2011).

\section{References}

Aircraft platforms [online], [cited 04 November 2013]. 2012. General Atomics Aeronautical. Available from Internet: http://www.gaasi.com/products/aircraft/pdf/Predator_B.pdf

Aircraft platforms [online], [cited 24 February 2014]. 2013. General Atomics Aeronautical. Available from Internet: http://www.ga-asi.com/products/aircraft/pdf/MQ-1_Predator.pdf

Appendix A: mission summaries [online]. 2006. Civil UAV Assessment [cited 04 November 2013]. Available from Internet: http://www.uavm.com/images/NASA_CT_Appendix_A.pdf

Earth observations and the role of UAVs: a capabilities assessment [online], [cited 04 November 2013]. 2006. Civil UAV Assessment Team. Available from Internet: http://www.nasa.gov/centers/dryden/pdf/175939main Earth_Obs_UAV_Vol_1_v1.1_Final.pdf

Hołdanowicz, G.; Makowski, T.; Hypki, T. 2000. Jeden czy dwa? Napęd samolotów bojowych, Skrzydlata Polska 1(2000) (in Polish).

Jurecka, R.; Bencalik, K. 2012. Airplanes with an electric motor, Aviation 16(3): 63-68. http://dx.doi.org/10.3846/16487788.2012.732304

Kulyk, M.; Kharchenko, V.; Matiychyk, M. 2011. Justification of thrust vector deflection of twin-engine unmanned aerial vehicle power plants, Aviation 15(1): 25-29. http://dx.doi.org/10.3846/16487788.2011.566319

Military OEM passes two milestones in unmanned aircraft contracts aviation reference [online], [cited 04 November 2013]. 2012. Unmanned Ground, Aerial, Sea and Space Systems. Available from Internet: http://www.unmanned. co.uk/unmanned-vehicles-news/unmanned-aerial-vehicles-uav-news/military-oem- passes-two-milestones-inunmanned-aircraft-contracts

Unmanned system integrated roadmap FY 2009-2034 [online], [cited 04 November 2013]. 2009. Department of Defense. Available from Internet: http://www.dtic.mil/get-tr-doc/ pdf? Location=U2\&doc $=$ GetTRDoc.pdf\&AD=ADA522247

Valavanis, K. P. 2007. Advances in Unmanned Aerial Vehicles. University of South Florida Tampa USA. 543 p. http://dx.doi.org/10.1007/978-1-4020-6114-1

Valavanis, K. P. 2008. Advances in Unmanned Aerial Vehicles State of the Art the Road to Autonomy. University of South Florida Tampa USA. 568 p.

Virtual Aviation Reference [online], [cited 04 November 2013]. 2013. Redstar. Available from Internet: http://www.redstar. gr/Foto_red/Eng/UAV/StrizhVR.html 